\title{
Eklampsia Antepartum pada G5P4A0H3 Gravid Preterm 33-34 Minggu + Sindrom HELLP + AKI + IUFD
}

\author{
Esfi Triana ${ }^{1}$, Syahredi SA ${ }^{2}$
}

\begin{abstract}
Abstrak
Hipertensi merupakan komplikasi medis yang paling sering ditemukan selama kehamilan. Sebagai penyumbang yang bermakna terhadap morbiditas dan mortalitas maternal dan perinatal, hipertensi diperkirakan telah menjadi komplikasi pada sekitar $7 \%$ sampai $10 \%$ dari seluruh kehamilan. Preeklamsia dan eklamsia merupakan penyebab dari 30-40 \% kematian perinatal dan merupakan salah satu komplikasi obstetri yang banyak menimbulkan morbiditas dan mortalitas selain perdarahan dan infeksi. Preeklamsia adalah suatu sindroma penyakit yang bersifat polimorfik sehingga semua organ dapat terlibat, sedangkan eklamsia di sertai kejang pada preeklamsia tanpa adanya penyebab lain. Berikut akan dibahas kasus seorang wanita usia 29 tahun dengan diagnosis penurunan kesadaran ec eklampsia antepartum pada G5P4A0H3 gravid preterm 33-34 minggu + HELLP sindrom + AKI + IUFD.
\end{abstract}

Kata kunci: hipertensi, preeklamsia, eklamsia, HELLP sindrom

\begin{abstract}
Hypertension is the most common medical complication found during pregnancy. As a significant contributor to maternal and perinatal morbidity and mortality, hypertension is thought to have complicated complications in about $7 \%$ to $10 \%$ of all pregnancies. Preeclampsia and eclampsia are the causes of $30-40 \%$ of perinatal deaths and are one obstetric complication that causes morbidity and mortality in addition to bleeding and infection. Preeclampsia is a polymorphic disease syndrome so that all organs can be involved, while eclampsia is accompanied by seizures in preeclampsia without other causes. The following will be discussed the case of a 29-year-old woman with a diagnosis of decreased consciousness of antepartum eclampsia in G5P4AOL3 33-34 week of preterm pregnancy + HELLP syndrome $+A K I+I U F D$.
\end{abstract}

Keywords: hypertension, preeclampsia, eclampsia, HELLP syndrome

Affiliasi penulis: 1, Program Pendidikan Dokter Spesialis-1 Obstetri dan Ginekologi FK Unand, 2 Bagian Obstetri dan Ginekologi FK Unand

Korespondensi: Esfi Triana esfitriana@gmail.com Telp: 082320000773

\section{PENDAHULUAN}

Angka kejadian preeklamsia sangat bervariasi antara satu negara dengan negara lain. Insidensinya berkisar antara 5-10\% dari seluruh kehamilan dan menyebabkan 3-25 kali lipat peningkatan risiko komplikasi obstetrik yang berat. Preeklamsia dan eklamsia merupakan penyebab dari 30-40\% kematian perinatal di Indonesia. ${ }^{1}$ Preeklamsia (PE) secara umum dijelaskan sebagaimana terjadinya hipertensi dan proteinuria setelah usia kehamilan 20 minggu pada wanita yang sebelumnya normotensi. ${ }^{3,4}$

Mekanisme patofisiologi yang mendasari terjadinya preeklamsia sampai saat ini masih belum jelas. Namun demikian, adanya rangkaian proses mulai dari gangguan invasi dini trofoblas, penurunan perfusi plasenta, iskemia plasenta, dipercaya menjadi penyebab disfungsi endotel sistemik pada preeklamsia. $^{2}$

Preeklamsia dan eklampsia masih merupakan penyebab tingginya morbiditas dan mortalitas ibu dan anak. Mortalitas ibu di negara berkembang masih tinggi yaitu sekitar $5-10 \%$, di $A S<1 \%$, sedangkan kematian janin sekitar $40 \%$, di AS sekitar 12\% dengan 
penyebab kematian ibu terjadi disebabkan karena perdarahan otak, gagal jantung, edema paru, gagal ginjal dan berbagai bentuk kegagalan multiorgan. Preeklamsia adalah suatu sindroma penyakit yang bersifat polimorfik sehingga semua organ dapat terlibat, sedangkan eklamsia di sertai kejang pada preeklamsia tanpa adanya penyebab lain. ${ }^{2}$

\section{KASUS}

Seorang pasien wanita usia 29 tahun, datang ke IGD RSUP Dr. M Djamil Padang pada tanggal 12 Agustus pukul 23.15WIB rujukan RS Ibnu Sina Simpang Empat dengan diagnosis penurunan kesadaran ec eklampsia antepartum pada G5P4A0H3 gravid preterm 33-34 minggu + IUFD.Pasien awalnya mengeluhkan sakit kepala hebat yang diikuti oleh kejang selama sekitar 5 menit, kejang seluruh tubuh dan pasien tidak sadar setelah kejang. Pasien kemudian dibawa ke datang ke RS Ibnu Sina Simpang Empat. Dari pemeriksaan didapatkan TD 200/110 $\mathrm{mmHg}$. DJJ tidak ditemukan. Pemeriksaan fisik didapatkan esadaran Sopor dan Tekanan Darah 190/140 mmHg. Usia kehamilan didapatkan dari pemeriksaan US (Gambar 1)

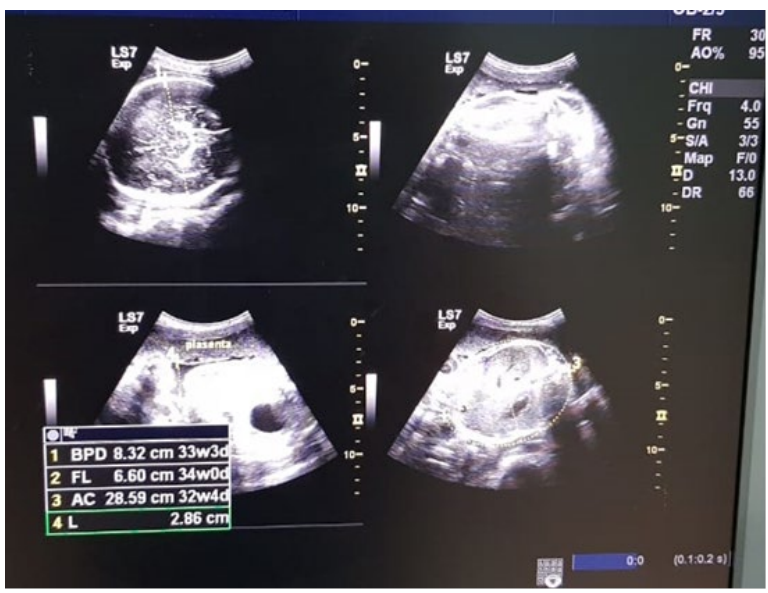

Gambar 1. Hasil USG

Pemeriksaan laboratorium ditemukan leukositosis, trombositopenia, tanda- HELLP sindrom, pada urin ditemukan protein positif 3 , hematuri (eritrosit400-600/LPB). Pasien kemudian dikonsultasi ke Penyakit Dalam, Jantung, Mata dan Neurologi. Pasien dirawat di ROI dan diberi terapi: oksigen 10 I/menit, IVFD RL 20 tpm, Lanjut regimen MgSO4, Drip Morphin 0,5 mg/jam, Drip sedacum $1 \mathrm{mg} / \mathrm{jam}$, Injeksi meropenem $3 \times 1 \mathrm{gr}$, Infus levofloxacine $1 \times 500 \mathrm{mg}$, Injeksi vitamin K 3x1 amp, Injeksi asam tranexamat 3x1 amp, Injeksi omeprazol 1x1 amp, Metildopa tab 500 mg (p.o) via NGT, Transfusi trombosit 10 unit.

Pasien direncanakan diterminasi kehamilan pervaginam dengan induksi $\rightarrow$ pematangan serviks dengan misoprostol 100 mcg tiap 6 jam pervaginam (mulai pukul 22.00 WIB). Setelah didapatkan skor Bishop 6 (dilatasi 1, konsistensi 1, panjang serviks 2, posisi serviks 1 , station 1 ), kemudian pasien diberi Drip oksitosin 5 unit dalam 500 cc RL mulai 5 tetes per menit, dinaikan 5 tetes setiap 30 menit sampai his adekuat atau maksimal 60 tetes per menit.

Hari kedua rawatan (14 Agustus 2018) didapatkan pasien mengalami anuria, anemia sedang, trombositopenia, peningkatan magnesium, ureum dan kreatinin. Sehingga pada pasien di stop regimen MgSO4, dilakukan transfusi trombosit 10 unit dan PRC 2 unit, dan Drip oksitosin 10 unit dalam 500 cc RL 30 tetes per menit. Setelah selama 7 jam di drip oksitosin pembukaan lengkap, ketuban (+), teraba kepala H3-4, dilakukan Amniotomi $\rightarrow$ bantu kala II dengan forcep ekatraksi. lahir bayi laki-laki, BB : 2300 gram, PB : $48 \mathrm{~cm}, \mathrm{~A} / \mathrm{S}$ : 0/0,Plasenta lahir lengkap 1 buah ukuran $15 \times 12 \times 2 \mathrm{~cm}$, Panjang tali pusat $50 \mathrm{~cm}$ berat 450 gram, insersi parasentralis dan Perdarahan $100 \mathrm{cc}$.

Pada hari ke 5 rawatan (17 Agustus 2018) fungsi ginjal pasien semakin memburuk, sehingga diputuskan dilakukan hemodialisis. Saat dilakukan hemodialisis tiba-tiba tekanan darah pasien tidak terukur, nadi tidak teraba. maka pasien dinyatakan meninggal dunia.

\section{PEMBAHASAN}

kasus Seorang wanita usia 29 tahun didiagnosis dengan penurunan kesadaran ec eklampsia antepartum dalam regimen $\mathrm{MgSO} 4$ dosis maintenance dari luar pada G5P4A0H3 gravid preterm 33-34 minggu + HELLP sindrom, Janin mati tunggal intrauterine presentasi kepala. Pasien masuk ruang KB IGD RSUP Dr. M. Djamil Padang pada tanggal 12 Agustus 2018 pada pukul 23.15 WIB rujukan dari RS Ibnu Sina Simpang Empat.

Dari alloanamnesis dengan suami dan bidan yang mengantar, pasien awalnya mengalami kejang di rumah satu kali, selama sekitar 5 menit, kejang 
seluruh tubuh, dan pasien tidak sadar setelah kejang. Kemudian pasien dibawa ke RS Ibnu Sina Simpang Empat. Dari pemeriksaan didapatkan TD 200/110 $\mathrm{mmHg}$. DJJ tidak ditemukan. Setelah dilakukan informed consent, pasien segera dirujuk ke RSUP Dr. M Djamil Padang dengan terpasang regimen MgSO4 dan kateter urin.

Alloanamnesis juga didapatkan adanya riwayat sakit kepala sebelum kejang. Nyeri pinggang menjalar ke ari-ari (-). Keluar lendir campur darah dari kemaluan (-). Keluar air-air yang banyak dari kemaluan (-). Tidak haid sejak \pm 8 bulan yang lalu. Pada pasien perkiraan usia kehamilan tidak dapat ditentukan berdasarkan HPHT, karena HPHT tidak ingat. Gerak anak mulai dirasakan sejak \pm 4 bulan yang lalu. RHM : Mual (-), Muntah(-), Perdarahan (-). ANC: teratur setiap bulan ke bidan sejak usia kehamilan 3 bulan dan pada usia kehamilan 7 bulan, pasien didapatkan tekanan darah tinggi kemudian pasien dianjurkan kontrol ke rumah sakit, tapi belum dilakukan oleh pasien.

Dari pemeriksaan fisik didapatkan keadaan umum berat, kesadaran sopor, tekanan darah didapatkan 190/140 mmHg, nadi 128 kali/menit, nafas 28 kali/menit dan saturasi oksigen 90\% dengan oksigen via nasal kanul 4 L/mnt. Mata konjungtiva tidak anemis, sklera tidak ikterik. Pada status obstetrikus, inspeksi perut tampak membuncit sesuai usia kehamilan 8 bulan. Palpasi dengan interpretasi FUT teraba pada pertengahan pusat dan proc. xiphoideus dengan teraba janin presentasi kepala, dengan bagian terbawah janin sudah memasuki pintu atas panggul, denyut jantung janin tidak ditemukan. Jumlah urin ketika masuk 100 cc sewaktu, warna merah kehitaman.

Pemeriksaan penunjang USG kesan gravid 3334 minggu sesuai biometri, IUFD, presentasi kepala. Dari pemeriksaan laboratorium didapatkan $\mathrm{Hb} \quad 13,7$ $\mathrm{gr} / \mathrm{dl}$, leukosit 22.450/mm3, trombosit 43.000/mm3, SGOT/SGPT 1020/236 U/L, ureum/kreatinin 46/0,5 mg/dL, LDH 9912 U/L, D-dimer reagen kosong, PT 13,0 detik, APTT 41,4 detik. Hasil urinalisa protein urin +4, leukosit 10-15 LPB, eritrosit 400-600/LPB.

Saat itu ditegakkan diagnosis Penurunan kesadaran ec eklampsia antepartum dalam regimen $\mathrm{MgSO} 4$ dosis maintenance dari luar pada G5P4A0H3 gravid preterm 33-34 minggu + HELLP sindrom, janin mati tunggal intrauterine presentasi kepala.

Penatalaksanaan pasien ini pada saat datang assesment awal untuk memastikan kondisi pasien yang datang dalam keadaan tidak sadar. Dari assesment awal didapatkan airway patent, breathing spontan dengan pemberian oksigen $4 \mathrm{~L} / m e n i t$ via nasal kanul dan sirkulasi didapatkan adanya hipertensi emergensi dengan TD 190/140 mmHg. Pasien sudah mendapatkan regimen MgSO4 dari luar. Pada pasien kemudian dilakukan penatalaksanaan berupa kontrol $\mathrm{KU}$, VS, balans cairan, dan refleks patella, oksigen via kanul nasal 4 l/menit, lanjut regimen MgSO4 dosis maintenance, Informed consent, darah lengkap (faal ginjal, faal hepar, fungsi hemostasis, AGD), EKG, USG, lapor tim PEB (mata, jantung, P.dalam) dan direncanakan terminasi kehamilan

Secara konseptual Acut Kidney Injury (AKI) adalah penurunan cepat (dalam jam hingga minggu) laju filtrasi glomerulus (LFG) yang umumnya berlangsung reversibel, diikuti kegagalan ginjal untuk mengekskresi sisa metabolisme nitrogen, dengan/ tanpa gangguan keseimbangan cairan dan elektrolit. ${ }^{5}$

Evaluasi dan manajemen awal pasien dengan Cedera Ginjal Akut (AKI) harus mencakup:

1. sebuah assessment penyebab yang berkontribusi dalam cedera ginjal

2. penilaian terhadap perjalanan klinis termasuk komorbiditas,

3. penilaian yang cermat pada status volume, dan

4. langkah-langkah terapi yang tepat yang dirancang untuk mengatasi atau mencegah memburuknya fungsional atau struktural abnormali ginjal.

Penilaian awal pasien dengan AKI klasik termasuk perbedaan antara prerenal, renal, dan penyebab pasca-renal. ${ }^{6}$ Diagnosis AKI saat ini dibuat atas dasar adanya kreatinin serum yang meningkat dan blood urea nitrogen (BUN) dan urine output yang menurun. $^{7}$

Cedera ginjal akut didefinisikan ketika salah satu dari kriteria berikut terpenuhi $:^{8}$

- Serum kreatinin naik sebesar $\geq 26 \mu \mathrm{mol} / \mathrm{L}$ dalam waktu 48 jam atau

- Serum kreatinin meningkat $\geq 1,5$ kali lipat dari nilai referensi, yang diketahui atau dianggap telah terjadi 
dalam waktu satu minggu atau

- Output urine $<0.5 \mathrm{ml} / \mathrm{kg} / \mathrm{hr}$ untuk $>6$ jam berturut-turut

ADQI mengeluarkan sistem klasifikasi AKI dengan kriteria RIFLE yang menggambarkan beratnya penurunan fungsi ginjal dan prognosis gangguan ginjal. $^{5}$

Tabel 1. Perbandingan antara kriteria diagnosis RIFLE dan AKIN. ${ }^{7}$

\begin{tabular}{|c|c|c|}
\hline$\frac{\frac{R I F L E}{\text { Criteria }}}{\text { Class }}$ & GFR Criteria & $\begin{array}{l}\text { Urine output } \\
\text { criteria }\end{array}$ \\
\hline R-Risk & $\begin{array}{l}\text { Creatinin increase } \times 1,5 \text { or } \\
\text { GFR loss }>25 \%\end{array}$ & $\begin{array}{l}0,5< \\
\mathrm{ml} / \mathrm{kg} / \text { hour }> \\
6 \text { hours }\end{array}$ \\
\hline I-Injury & $\begin{array}{l}\text { Creatinin increase } \times 2 \text { or } \\
\text { GFR loss }>50 \%\end{array}$ & $\begin{array}{l}0,5< \\
\mathrm{ml} / \mathrm{kg} / \text { hour }> \\
12 \text { hours }\end{array}$ \\
\hline $\begin{array}{l}\text { F- } \\
\text { Failure }\end{array}$ & $\begin{array}{l}\text { Creatinin increase } \times 3 \text { or } \\
\text { GFR loss }>75 \% \text { Creatinin } \\
\text { increase } \times 4 \mathrm{mg} / \mathrm{dl} \text { (acute } \\
\text { increase }>0,5 \mathrm{mg} / \mathrm{dl} \text { ) }\end{array}$ & $\begin{array}{l}0,5< \\
\mathrm{ml} / \mathrm{kg} / \mathrm{hour}> \\
12 \text { hours }\end{array}$ \\
\hline L-Loss & $\begin{array}{l}\text { Persistent loss of kidney } \\
\text { function }>4 \text { weeks }\end{array}$ & \\
\hline $\begin{array}{l}\text { E- } \\
\text { ESKD }\end{array}$ & ESKD $>3$ months & \\
\hline $\begin{array}{l}\text { AKIN } \\
\text { Ceriteria } \\
\text { Stage }\end{array}$ & Serum Creatinin Criteria & $\begin{array}{l}\text { Urine Output } \\
\text { criteria }\end{array}$ \\
\hline 1 & $\begin{array}{l}\text { Creatinin increase } \times 1,5 \text { or } \\
\text { creatinine increase }>0,3 \\
\mathrm{mg} / \mathrm{dl}\end{array}$ & $\begin{array}{l}0,5<\mathrm{mg} / \mathrm{kg} / \text { hour } \\
x>6 \text { hours }\end{array}$ \\
\hline 2 & Creatinine increase $\times 2$ & $\begin{array}{l}0,5<\mathrm{mg} / \mathrm{kg} / \text { hour } \\
x>12 \text { hours }\end{array}$ \\
\hline 3 & $\begin{array}{l}\text { Creatinin increase } \times 3 \text { or } \\
\text { creatinine increase }>4 \\
\mathrm{mg} / \mathrm{dl} \text { (acute increase }>0,5 \\
\mathrm{mg} / \mathrm{dl}\end{array}$ & $\begin{array}{l}0,5<\mathrm{mg} / \mathrm{kg} / \text { hour } \\
x>24 \text { hours or } \\
\text { Anuria }>12 \text { hours }\end{array}$ \\
\hline
\end{tabular}

Adanya komplikasi AKI seperti misalnya hipervolemia, edema paru akut atau keseimbangan cairan besar kumulatif positif, hiperkalemia, asidosis metabolik ( $\mathrm{pH}$ kurang dari 7,1) dan gejala uremik (mual dan muntah persisten, perikarditis, neuropati, atau tidak jelas penyebabnya penurunan status mental) dialisis harus dipertimbangkan sebagai terapi andalan. Angka kematian pada pasien dengan AKI tetap lebih besar dari $50 \%$ pada pasien sakit berat. Ada kemungkinan bahwa variasi dalam waktu inisiasi, modalitas, dan/atau dosis dari RRT dapat mempengaruhi hasil klinis, khususnya kelangsungan hidup. $^{7}$

Beberapa indikasi utama untuk melakukan terapi pengganti Ginjal adalah sebagai berikut : ${ }^{9}$

- Fluid overload

- Metabolic acidosis

- Oliguria (urine output $<200 \mathrm{~mL} / 12 \mathrm{~h}$ )

- Anuria /extreme oliguria (urine output $<50 \mathrm{~mL} / 12 \mathrm{~h}$ )

- Hyperkalemia ([K]>6.5 mEq/L)

- Clinically significant organ (especially pulmonary) edema

- Uremic encephalopathy

- Uremic pericarditis

- Uremic neuropathy/myopathy

- Severe dysnatremia ([Na] $<115$ or $>160 \mathrm{mEq} / \mathrm{L})$

- Hyperthermia

- Drug overdose with filterable toxin (lithium, vancomycin, procainamide, etc)

- Imminent or ongoing massive blood product administration

Penyebab kematian pasien ini adalah kegagalan fungsi organ yang disebabkan oleh gagal ginjal. Sindrom HELLP sering diikuti oleh gagal ginjal akut (AKI). Nekrosis kortikal akut (Acute renal cortical necrosis, ARCN) dapat dipertimbangkan ketika gagal ginjal akut berkembang dari sindrom HELLP. Kecurigaan meningkat saat fungsi ginjal gagal pulih dalam 2-3 minggu

\section{SIMPULAN}

Kasus ini merupakan sebuah kasus terminal dari eklampsia yang disertai HELLP Syndrome yang disertai kegagalan multiorgan. Kasus seperti ini merupakan sebuah contoh kasus kegagalan dalam penanganan pasien sejak prekonsepsi, ANC, serta penatalaksaan di pelayanan kesehatan.

Morbiditas dan mortalitas pada pasien terjadi karena adanya keterlambatan dalam penanganan pasien, yaitu: Keterlambatan dalam melakukan deteksi dini pasien sehingga pasien jatuh kedalam kondisi eklampsia, Keterlambatan dalam melakukan terminasi kehamilan serta pemilihan metode terminasi, Keterlambatan dalam pemutusan melakukan hemodialisis. 


\section{DAFTAR PUSTAKA}

1. Umans JG, Lindheimer MD. Antihypertensive therapy in pregnancy. Current Hypertension Reports. September 2001;3(5):392-9.

2. Cunningham FG, Leveno KJ, Bloom SL, Spong $\mathrm{CY}$, Dashe JS, Hoffman BL, et al. Williams Obstetric. Edisi ke-24. McGraw-Hill Companies. 2014.

3. Walker JJ. Pre-eclampsia. Lancet. 2000 Oct 7; 356 (9237):1260-5.

4. Robert JM, August PA, Bakris G, Barton JR, Bernstein IM, Druzin $\mathrm{M}$, et al. Hypertension in pregnancy. ACOG. 2013.

5. Sinto R, Nainggolan G. Acute kidney injury: pendekatan klinis dan tata laksana. Maj Kedokt Indon. 2010; 60:2.
6. Himellfarb J, Joannidis M, Molitoris B, Schietz $\mathrm{M}$, Okusa MD, Warnock $D$, et al. Evaluation and initial mangement of acute kidney injury. Clin J Am Soc Nephrol. 2008; 3: 962-7.

7. Akcay A, Turkmen K, Lee DW, Edelstein CL. Update on the diagnosis and management of acute kidney injury. International Journal of Nephrology and Renovascular Disease. 2010; 3: $129-40$.

8. Lewington A, Kanagasundaram A. AKI: Definition, epidemiology, and outcomes, clinical pratice AKI guideline. Nephron Clin Pract 2011;118(suppl 1):c349-90.

9. Dube S, Sharma VK. Renal replacement therapy in intensive care unit. J Assoc Physicians India. 2009 Oct;57:708-12. 